\title{
PENGETAHUAN DAN
}

Volume 7, Nomor 1, April 2019

\section{KETERAMPILAN DALAM \\ PENGOLAHAN BAHAN MAKANAN \\ MENCEGAH STUNTING PADA ANAK \\ USIA DINI}

\author{
Ismaniar ${ }^{1,2}$ \\ ${ }^{1}$ Jurusan Pendidikan Luar Sekolah Fakultas Ilmu Pendidikan Universitas Negeri Padang \\ 2Email: ismaniar.js.pls@fip.unp.ac.id
}

\begin{abstract}
A healthy, intelligent and noble child is the dream of all parents. But to create a healthy generation, there are various problems, including many cases of stunting that occur in children, especially early childhood. Stunting is a problem of chronic malnutrition which results in growth disorders in children. Stunting factors include food patterns, parenting, and sanitation patterns. One solution to overcome the problem of stunting in children is the need for knowledge and skills in processing food ingredients and food displays. Armed with the knowledge and skills of processing and displaying food, housewives can serve nutritious and attractive food for children's consumption.
\end{abstract}

Keywords: Stunting, Knowledge, Skills, Processing, Food Ingredients

\begin{abstract}
ABSTRAK
Anak yang sehat, cerdas dan berakhlak mulia merupakan dambaan dari semua orang tua. Namun dalam upaya menciptakan generasi yang sehat, terdapat berbagai permasalahan, di antaranya banyak muncul kasus stunting yang terjadi pada anak, khususnya anak usia dini. Stunting adalah masalah kurang gizi kronis yang mengakibatkan gangguan pertumbuhan pada anak. Faktor penyebab stunting di antaranya pola makanan, pola pengasuhan dan sanitasi. Salah satu solusi dalam mengatasi masalah stunting pada anak adalah perlunya pengetahuan dan keterampilan dalam pengolahan bahan makanan dan display makanan. Berbekal pengetahuan dan keterampilan mengolah dan mendisplay makanan, ibu rumah tangga dapat menyajikan makanan yang bergizi serta menarik untuk dikonsumsi anak.
\end{abstract}

Kata Kunci: Stunting, Pengetahuan, Keterampilan, Pengolahan, Bahan Makanan 
Knowledge and Skills in Processing of Food Materials Preventing Stunting in Early Childhood...

\section{PENDAHULUAN}

Dari info yang dilansir oleh WHO (dalam Nadimin, 2018), Indonesia merupakan salah satu negara yang masuk pada kategori darurat stunting. Stunting merupakan suatu bentuk gangguan pertumbuhan dan perkembangan pada anak yang diakibatkan oleh kurang terpenuhinya asupan nutrisi dan gizi yang dibutuhkan anak (Pusdatin Kemenkes, 2018; Tim Nasional Percepatan Penanggulangan Kemiskinan, 2017). Lebih jelas menurut WHO, stunting adalah kondisi gagal tumbuh. Ini bisa dialami oleh anak-anak yang mendapatkan gizi buruk, terkena infeksi berulang, dan stimulasi psikososialnya tidak memadai (Nadimin, 2018; Pusdatin Kemenkes, 2018).

Damayanti Rusli Sjarif (dalam Arbar, 2019) seorang pakar nutrisi dan penyakit metabolik anak menjelaskan bahwa akibat dari stunting bukan sekadar terganggunya tinggi badan anak. Apabila bentuk gangguan yang dialami anak hanya berupa terganggunya pertumbuhan tinggi badan, masih ada kesempatan kedua untuk memperbaikinya. Namun jika kondisi stunting yang dialami anak sudah sampai pada terganggunya pertumbuhan otak, persoalannya akan berbeda karena sampai sekarang belum ada obatnya.

Bermunculannya kasus stunting dan masuknya negara Indonesia sebagai salah satu negara yang darurat stunting menurut data WHO bisa disebabkan karena banyak faktor, di antaranya kondisi ekonomi masyarakat yang kurang stabil karena gejolak harga berbagai kebutuhan harian yang relatif naik, sehingga kemampuan masyarakat melemah dalam mencukupi kebutuhan anaknya (Pusdatin Kemenkes, 2018). Kondisi lain juga bisa dikarenakan kurangnya pengawasan keluarga dan lingkungan terhadap asupan makanan yang dikonsumsi anak, serta bisa juga karena lemahnya pengetahuan dan keterampilan orang tua dalam mengolah dan men-display makanan untuk anak sehingga anak kurang tertarik untuk makan makanan rumah dan tergandung pada makanan instan.

Sehubungan dengan begitu berbahayanya dampak yang ditimbulkan jika anak mengalami gangguan Stunting maka orang tua harus sangat berhati-hati dan menyiapkan diri dengan berbagai pengetahuan dan keterampilan yang dapat mencegah munculnya gangguan tersebut. Untuk itu, tulisan ini bertujuan membahas tentang pengetahuan dan keterampilan ibu dalam pengolahan bahan makanan dan display makanan sebagai solusi untuk mencegah bahaya stunting pada anak.

\section{PEMBAHASAN}

\section{Konsep Tentang Tumbuh Kembang Anak}

Usia dini merupakan waktu yang paling identik dengan masa-masa pesatnya pertumbuhan dan perkembangan setiap anak. Setiap orang tua harus memiliki pemahaman yang benar tentang hal ini, agar mereka dapat mendukung terjadinya pertumbuhan dan perkembangan anak secara optimal. Begitu pentingnya masa usia dini bagi tumbuh kembang anak maka seringkali para pakar pendidikan dan perkembangan menyebut usia dini sebagai usia emas (golden age) setiap individu. Jika pada masa-masa usia dini pertumbuhan dan perkembangan anak bisa distimulasi dengan baik, maka berbagai keuntungan dapat diperoleh anak dalam perkembangan di usia selanjutnya. Sebaliknya jika di masa usia dini perkembangan dan pertumbuhan anak terabaikan, maka anak akan mengalami kerugian untuk perkembangan di usia selanjutnya (Santrock, 2011). 
Selanjutnya untuk memahami pengertian tumbuh kembang anak, maka dapat dipahami melalui pendapat para pakar pendidikan dan perkembangan. Menurut Jamaris (2004) hakikat pertumbuhan adalah suatu proses perubahan yang bersifat kuantitatif pada setiap individu dan berpengaruh pada perkembangannya. Sementara Montessory (dalam Sujiono, 2009) menjelaskanmasa usia dini merupakan periode sensitif (sensitive periods), pada masa ini anak mudah menerima stimulus dari lingkungannya. Pada masa sensitif ini terjadi pematangan fungsi fisik dan psikis pada anak, sehingga mereka mudah merespon dan menuntaskan tugas perkembangannya. Begitu pentingnya masa usia dini untuk pertumbuhan dan perkembangan anak maka perlu perhatian dari orang tua sebagai penanggung jawab utama seorang anak.

\section{Konsep Tentang Makanan Gizi Seimbang}

Perkembangan kesehatan pada anak tidak bisa dilepaskan dari asupan gizi yang diterimanya. Kebutuhan asupan gizi pada anak tersebut tidak bisa terpenuhi dengan hanya mengandalkan satu jenis makanan saja. Adapun beberapa kandungan gizi yang dibutuhkan untuk menjamin kesehatan anak, di antaranya protein, karbohidrat, vitamin, lemak serta mineral. Berbagai jenis bahan makanan yang ada di sekitar kita dapat dipadu padankan untuk mencukupi kebutuhan gizi anak. Jika keberagaman jenis bahan makanan dapat disediakan yang dikenal dengan istilah makanan gizi seimbang, maka kekurangan zat gizi pada satu jenis makanan dapat terpenuhi dari bahan makanan yang lainnya (Santoso, 2010).

Kebutuhan akan gizi yang dapat disajikan dalam hidangan berupa makanan gizi seimbang, selain diperlukan untuk menjamin terjadinya pertumbuhan anak secara fisik, seperti meningkatkan jumlah serta ukuran sel-sel tubuh anak juga ditujukan untuk mengoptimalkan perkembangan sel-sel otak. Perkembangan sel-sel otak menjadi suatu tujuan utama karena dapat menjadi dasar perkembangan kecerdasan setiap anak. Untuk itu, kecukupan pemenuhan asupan nutrisi dan gizi sangat menentukan kesehatan dan imunitas setiap anak akan gangguan berbagai penyakit, termasuk gangguan stunting.

\section{Konsep Tentang Stunting}

Istilah stunting cukup familiar kita dengar akhir-akhir ini terutama dalam kegiatan pertemuan dan pembicaraan ilmiah di bidang kesehatan dan pendidikan anak. Namun istilah stunting ini masih belum dipahami dengan baik oleh masyarakat secara umum, padahal kasus stunting pada dasarnya banyak ditemukan di tengah masyarakat. Menyimak pengertian stunting yang dikemukakan oleh depkes RI, dijelaskan bahwa stunting adalah masalah kurang gizi kronis yang disebabkan oleh kurangnya asupan gizi dalam waktu yang cukup lama, sehingga mengakibatkan gangguan pertumbuhan pada anak yakni tinggi badan anak lebih rendah atau pendek (kerdil) dari standar usianya (Buku Saku Desa dalam Penanganan Stunting, 2017). Stunting tidak terjadi hanya karena satu sebab, namun ada beberapa faktor yang dapat menyebabkan terjadinya stunting pada anak. Menurut Mentri kesehatan RI ibu Nila Farid Moelok (dalam Andini 2018); setidaknya ada beberapa faktor yang menyebabkan terjadinya stunting yaitu terkait pola makan, pola asuh, serta sanitasi dan akses air bersih.

Berdasarkan penjelasan di atas, untuk menghindari anak terdampak stunting maka langkah cerdas yang dapat dilakukan semua pihak terutama orang tua adalah dengan memperhatikan pola makan anak, melaksanakan pola asuh yang tepat, memperbaiki sanitasi serta akses air bersih untuk perawatan anak sehari-hari. 
Knowledge and Skills in Processing of Food Materials Preventing Stunting in Early Childhood...

\section{Pengetahuan dan Keterampilan Pengolahan Bahan Makanan dan Display Makanan untuk Anak Solusi Mencegah Stunting}

Memahami begitu berbahayanya dampak yang terjadi akibat stunting, maka perlu upaya untuk pencegahan. Lebih jauh mengacu pada faktor yang menyebabkan terjadinya stunting, maka salah satu yang harus diperhatikan oleh orang tua adalah pola makan dan asupan nutrisi/gizi yang dibutuhkan anak. Keluarga sebagai penanggung jawab utama kesehatan dan tumbuh kembang anak, terutama seorang ibu seharusnya memiliki pengetahuan dan keterampilan mengenai pola makanan, pengolahan dan display makanan.

Seorang ibu yang memiliki pengetahuan yang baik tentang pola makanan dan aneka jenis bahan makan, dapat memilih makanan yang akan disiapkannya untuk anak. Mereka tidak mungkin akan menyediakan makanan secara sembarangan untuk anaknya. Jadi dengan demikian setiap makanan yang diberikan untuk anak dapat dipastikan membuat akan sehat.

Selanjutnya terkait dengan keterampilan pengolahan bahan makanan. Seorang ibu tidak hanya dituntut untuk memiliki pengetahuan tentang berbagai jenis bahan makanan yang dibutuhkan anak, akan tetapi juga seharusnya memiliki keterampilan mengolah bahan makanan. Keterampilan mengolah bahan makanan menjadi penting karena bagaimanapun bagusnya bahan makanan, namun jika pengolahannya tidak benar, maka makanan yang diolah akan kehilangan gizi yang dikandungnya. Jadi, dengan demikian cara pengolahan makanan sangat menentukan apakah makanan yang disajikan untuk anak bagus untuk kesehatannya.

Kurangnya ketertarikan anak dalam mengonsumsi makanan yang disajikan bisa juga terjadi karena cara orang tua menyajikan atau men-display makanan. Sebagaimana dijelaskan oleh Piaget (dalam Papalia, Old, Feldman, \& D, 2008), anak usia dini dalam tahap perkembangannya masih berada pada tahap sensori motor dan pra-operasional konkret. Menyikapi hal tersebut maka orang tua harus memahami bahwa anak sangat tertarik pada bentuk, penampakan dan warna benda atau sesuatu yang ada di sekitarnya, termasuk halnya dalam makanan. Kecenderungan anak-anak sekarang ini lebih menyukai makanan siap saji atau makanan instan salah satunya juga karena tampilan dari makanan itu sendiri. Jadi, jika kemampuan seorang ibu menyajikan makanan baik maka anak-anak akan tertarik untuk mengonsumsi makanan rumah yang disajikan. Sebaliknya jika seorang ibu hanya menyajikan makanan untuk anak dengan sajian sederhana dan monoton maka anak akan beralih kepada makanan instan atau siap saji, sehingga anak mengalami kurang gizi dan akhirnya terganggu pertumbuhannya (stunting).

\section{KESIMPULAN}

Berdasarkan pembahasan yang telah diuraikan, maka dapat disimpulkan: 1) Stunting merupakan salah satu gangguan kesehatan pada anak yang terjadi sejak anak masih bayi yang memiliki dampak pada pertumbuhan dan kecerdasan anak untuk jangka panjang; 2) Di antara faktor yang menyebabkan terjadinya stunting pada anak adalah pola makan dan pola pengasuhan anak yang tidak benar, sanitasi dan sumber air yang tidak higenis; 3) Salah satu solusi yang dapat dilakukan untuk mencegah terjadinya stunting adalah dengan meningkatkan pengetahuan dan keterampilan ibu dalam memilih bahan makanan, mengolah makanan dan men-display makanan. 


\section{DAFTAR RUJUKAN}

Andini, R. (2018). Indonesia Darurat Stunting, Masak Sih?

Arbar, T. F. (2019, March 13). Stunting Tidak Hanya Soal Tinggi Badan Anak. GATRAcom. Retrieved from https://www.gatra.com/detail/news/398994-Stunting-TidakHanya-Soal-Tinggi-Badan-Anak

Buku Saku Desa dalam Penanganan Stunting. (2017). Jakarta: Kementerian Desa Pembangunan Daerah Tertinggal dan Transmigrasi.

Jamaris, M. (2004). Perkembangan dan Pengembangan Anak Usia Taman Kanak-Kanak. Jakarta: PPS Pendidikan Anak Usia Dini UNJ.

Nadimin, N. (2018). Pola Makan, Keadaan Kesehatan dan Suapan Zat Gizi Anak Balita Stunting di Moncong Loe Kabupaten Maros Sulawesi Selatan. Media Kesehatan Politeknik Kesehatan Makassar, 13(1), 48. https://doi.org/10.32382/medkes.v13i1.94

Papalia, D. E., Old, S. W., Feldman, \& D, R. (2008). Human Development. Jakarta: Prenada Media Group.

Pusdatin Kemenkes. (2018). Situasi Balita Pendek (Stunting) di Indonesia. Buletin Jendela Data Dan Informasi Kesehatan, 1, 2.

Santoso, S. (2010). Kesehatan Giæi. Jakarta: Universitas Terbuka.

Santrock, J. W. (2011). Masa Perkembangan Anak. Jakarta: Salamba Humanika.

Sujiono, Y. N. (2009). Konsep Dasar Pendidikan Anak Usia Dini. Jakarta: PT Indeks.

Tim Nasional Percepatan Penanggulangan Kemiskinan. (2017). 100 Kabupaten/Kota Prioritas untuk Intervensi Anak Kerdil (Stunting). Jakarta: Sekretariat Wakil Presiden Republik Indonesia. 